\title{
Pengaruh Motif Penggunaan Media Sosial Instagram @sisilism Terhadap Kepuasan Followers Terkait Sex Education
}

\author{
Felicia Clairine, Widayatmoko \\ felicia.915150169@stu.untar.ac.id,widayatmoko@fikom.untar.ac.id
}

Fakultas Ilmu Komunikasi Universitas Tarumanagara

\begin{abstract}
In Indonesia, the topic of sex education is still considered taboo by most people. Therefore, sex education is almost never taught by parents or teachers. The presence of social media like Instagram provides its own color for young people in seeking entertainment or information. One of them is the Instagram @ sisilism account that discusses sex education in detail and is easy to understand. The purpose of this research was to determine the influence of Instagram @ sisilism on satisfaction followers related to sex education. The main theories used in this reasearch are the uses and gratification theory, motives, and satisfaction. The method used is a quantitative descriptive method by taking a sampling technique in the form of non-propability sampling method and purposive sampling approach. The population in this study were 46.1 thousand followers of Instagram @ sisilism with a sample of 300 respondents. After the questionnaire was distributed, an analysis of validity, reliability, normality, correlation coefficient, coefficient of determination, simple regression, and hypothesis testing or t test were carried out. The result of the research reveals that the motive of using Instagram @ sisilm significantly affected followers satisfaction related to sex education. With the findings of personal identity and information motiveswhich related to the type of sexuality and sex education knowledge influence followers' satisfaction in using Instagram @ sisilism related to sex education.
\end{abstract}

Keywords: sex education, motives, satisfaction, Instagram

\begin{abstract}
Abstrak
Di Indonesia, topik mengenai sex education masih dianggap tabu oleh sebagian besar orang, sehingga informasi sex education hampir tidak pernah diajarkan oleh orang tua ataupun guru. Media sosial Instagram lewat akun @sisilism membahas mengenai sex education secara rinci dan mudah dimengerti. Tujuan penelitian ini adalah untuk mengetahui adanya pengaruh antara media sosial Instagram @ sisilism terhadap kepuasan followers terkait sex education. Teori utama yang digunakan dalam penelitian ini adalah teori uses and gratification, motif, dan kepuasan. Metode yang digunakan adalah metode deskriptif kuantitatif dengan pengambilan teknik sampling berupa metode nonn propability sampling dan teknik pendekatan purposive sampling. Populasi pada penelitian ini sebanyak 46,1 ribu followers Instagram@sisilism dengan jumlah sampel sebanyak 300 responden. Setelah kuesioner disebarkan, dilakukan analisis validitas, reliabilitas, normalitas, koefisien korelasi, koefisien determinasi, regresi sederhana, dan uji hipotesis atau uji t. Hasil penelitian mengungkapkan bahwa motif penggunaan media sosial Instagram @ sisilism mempengaruhi secara signifikan kepuasan followers terkait sex education. Hasil penelitian menunjukkan bahwa motif identitas pribadi yang berkaitan dengan tipe seksualitas dan motif informasi yang berkaitan dengan pengetahuan sex education mempengaruhi kepuasan followers dalam menggunakan media sosial Instagram @sisilism terkait sex education.
\end{abstract}

Kata Kunci: Sex education, motif, kepuasan, Instagram 


\section{Pendahuluan}

Sex education merupakan topik pembahasan yang dianggap tabu oleh banyak orang, khususnya di Indonesia. Padahal, pendidikan mengenai seks sangat dibutuhkan oleh semua orang bahkan sejak usia dini. Namun, masih banyaknya masyarakat yang memiliki pemikiran tradisional menganggap bawa pengajaran seks selalu berkaitan dengan hubungan seksual. Nyatanya, pendidikan seks tidak selalu membahas tentang hubungan seksual, melainkan tentang penamaan fungsi seksual, organ fisik lainnya, bahkan cara mencegah penularan penyakit seksual. Pemahaman seperti inilah yang kemudian membuat banyak orang merasa canggung. Minimnya pengajaran akan sex education menimbulkan beberapa efek di kalangan anak muda Indonesia seperti pergaulan bebas, bahkan dapat memberikan efek yang lebih dalam.

Data dari Survey Demografi dan Kesehatan Indonesia (SDKI) 2017 mengungkap sekitar 2 persen remaja wanita $15-24$ tahun dan 8 persen remaja pria di rentang waktu sama telah melakukan hubungan seksual sebelum menikah dan 11 persen di antaranya mengaku mengalami kehamilan tidak diinginkan. Hubungan seksual menyimpang juga bisa meningkatkan penularan HIV-AIDS, apalagi kalau tidak dibarengi dengan pengetahuan mengenai kesehatan reproduksi. (https://health.detik.com/berita-detikhealth/d-4249233/gunung-es-perilaku-sekspranikah-di-kalangan-remaja dikases pada tanggal 9 Maret 2019 pada pukul 20.12 WIB). Padahal sejatinya, pengertian dari sex education adalah suatu informasi mengenai persoalan seksualitas manusia yang jelas dan benar. Informasi itu meliputi proses terjadinya pembuahan, kehamilan sampai kelahiran, tingkah laku seksual, hubungan seksual, dan aspek-aspek kesehatan, kejiwaan dan kemasyarakatan (Luthfie, 2009:152).

Menyadari minimnya pengajaran sex education, salah satu akun Instagram @ sisilism hadir dengan konten yang membahas sex education secara rinci dan mudah dimengerti, khususnya bagi kaum muda. Melalui Instagram ini diharapkan memenuhi kepuasan para kaum muda khususnya followers terkait sex education Instagram adalah media sosial yang bercerita melalui sharing video ataupun foto yang dapat dilihat dan dibagikan oleh semua orang. Menurut Bambang dalam buku Berkomunikasi Ala Net Generation (Budiargo, 2015:48), Instagram adalah suatu aplikasi yang berada pada sebuah smartphone berupa media digital berupa media sosial yang memiliki fungsi seperti twitter, dengan perbedaan pada pengambilan bentuk foto ataupun video.

Menurut Kotler, kepuasan adalah rasa sedih, kecewang, senang seseorang setelah membandingkan kesan ataupun persepsinya akan hasil suatu harapan ataupun produk. Dalam pemenuhan kepuasan followers tersebut, tentu ada motif yang melatar belakangi mereka dalam mengonsumsi media sosial Instagram khususnya melalui akun @sisilism. Motif merupakan suatu pengertian yang melengkapi semua penggerak alasan-alasan diri manusia yang menyebabkan ia berbuat sesuatu (Gerungan, 2002:140).

Berdasarkan pemaparan di atas, maka hipotesis dalam penelitian ini adalah :

Ho : Tidak terdapat pengaruh motif penggunaan media sosial Instagram @ sisilism terhadap kepuasan followers.

Ha : Terdapat pengaruh mootif penggunaan media sosial Instagram @sisilism terhadap kepuasan followers 
Tujuan penelitian ini adalah untuk mengetahui apakah terdapat pengaruh motif penggunaan media sosial Instagram @sisilism terhadap kepuasan followers terkait sex education.

\section{Metode Penelitian}

\begin{tabular}{|c|c|}
\hline $\begin{array}{l}\text { Motif Penggunaan } \\
\quad(\mathrm{X})\end{array}$ & $\begin{array}{l}\qquad \text { Kepuasan } \\
\qquad(\mathrm{Y}) \\
\text { 1. Attributes related to } \\
\text { the product } \\
\text { 2. Attributes related to } \\
\text { purchase }\end{array}$ \\
\hline
\end{tabular}

Gambar 1. Kerangkan Pemikiran (Variabel X dan Variabel Y)

Pendekatan yang digunakan dalam penelitian ini adalah deskriptif kuantitatif dengan metode penelitian survei. Metode survei adalah penyelidikan yang diadakan untuk memperoleh fakta-fakta dari gejala-gejala yang ada dalam mencari keteranganketerangan secata faktual, baik tentang institusi sosial, ekonomi, atau politik dari suatu kelompok ataupun suatu daerah. Penyelidikan dalam survei dilakukan dalam waktu yang bersamaan terhadap sejumlah individu atau unit, baik secara khusus atau dengan menggunakan sampel (Nazir, 2011:56).

Populasi dalam penelitian ini adalah seluruh followers pada akun Instagram @ sisilism yang berjumlah 44,6 ribu pada tanggal 26 Juni 2019 pukul 21.58. Sedangkan sampel dalam penelitin ini berjumlah 300 responden yang merupakan individu-individu yang pernah memberikan tanda like ataupun berkomentar pada setidaknya salah satu konten yang dibagikan akun @sisilism dalam kurun waktu 4 bulan terakhir (Februari-April 2019). Teknik pengambilan sampel menggunakan metode non propability sampling yang dipadukan dengan teknik pendekatan purposive sampling, yaitu yaitu teknik penentuan sampel dengan pertimbangan tertentu (Sugiyono, 2017 : 85). Data dikumpulkan dengan menyebarkan kuesioner dengan menggunakan skala Likert. Data primer pada penelitian ini diperoleh melalui hasil kuesioner yang disebarkan. Sedangkan data sekunder diperoleh melalui studi kepustakaan baik melalui buku, jurnal, ataupun internet. Pada penelitian ini, penulis menggunakan uji validitas, reliabilitas, dan normalitas guna mengetahui keabsahan data dalam penelitian ini. Setelah itu, peneliti juga melakukan uji koefisien korelasi, koefisien determinasi, regresi linear sederhana, dan uji t. 
Tabel 1 : Tabel Operasional Variabel

\begin{tabular}{|c|c|c|c|c|}
\hline No & Variabel & Dimensi & Indikator & Skala Data \\
\hline \multirow[t]{4}{*}{ 1.- } & Motif (X) & 1. Informasi & $\begin{array}{l}\text { a. Mengetahui peristiwa di sekitar } \\
\text { b. Mencari informasi atau berita yang } \\
\text { ramai dibicarakan }\end{array}$ & Nominal \\
\hline & & $\begin{array}{ll}\text { 2. } & \text { Identitas } \\
& \text { Pribadi }\end{array}$ & $\begin{array}{l}\text { c. Menemukan nilai yang berkaitan } \\
\text { dengan pribadi diri } \\
\text { d. Mencari nilai atau acuan dalam } \\
\text { bertindak atau berperilaku }\end{array}$ & Nominal \\
\hline & & $\begin{array}{ll}\text { 3. } & \text { Integrasi } \\
\text { dan } \\
\text { Identitas } \\
\text { Sosial }\end{array}$ & $\begin{array}{l}\text { e. Memperoleh pengetahuan dan } \\
\text { empati sosial } \\
\text { f. Mencari bahan percakapan dengan } \\
\text { orang lain dengan pembahasan topik } \\
\text { yang sama }\end{array}$ & Nominal \\
\hline & & $\begin{array}{ll}\text { 4. } & \text { Motif } \\
\text { Hiburan }\end{array}$ & $\begin{array}{l}\text { g. Melepaskan diri dari masalah } \\
\text { h. } \begin{array}{l}\text { Mengisi waktu luang, emosi, } \\
\text { bersantai,atau } \\
\text { masalah }\end{array}\end{array}$ & Nominal \\
\hline \multirow[t]{2}{*}{2.} & $\begin{array}{c}\text { Kepuasan } \\
(\mathbf{Y})\end{array}$ & $\begin{array}{l}\text { 1. Attributes } \\
\text { related to the } \\
\text { product }\end{array}$ & $\begin{array}{ll}\text { i. } & \text { Value - price relationship } \\
\text { j. } & \text { Product quality } \\
\text { k. } & \text { Product benefit } \\
\text { l. } & \text { Product features } \\
\text { m. } & \text { Product design } \\
\text { n. } & \text { Product reliability and consistency } \\
\text { o. } & \text { Range of product or service }\end{array}$ & Nominal \\
\hline & & $\begin{array}{l}\text { 2. Attributes } \\
\text { related to } \\
\text { purchase }\end{array}$ & $\begin{array}{ll}\text { p. } & \text { Courtesy } \\
\text { q. } & \text { Communication } \\
\text { r. } & \text { Ease/convenience acquisition } \\
\text { s. } & \text { Company reputation } \\
\text { t. } & \text { Company competence }\end{array}$ & Nominal \\
\hline
\end{tabular}

\section{Hasil Temuan dan Diskusi}

Untuk menguji instrumen, tiap butir pertanyaan dilakukan uji instrumen dengan mengambil sampel sebanyak 30 orang. Setelah dilakukan penyebaran angket, maka selanjutnya dilakukan pengolahan data untuk uji validitas, reliabilitas, dan normalitas.

Tabel 2. Hasil Analisis Validitas

\begin{tabular}{cccc}
\hline \multicolumn{2}{c}{ No Soal } & $\begin{array}{c}\text { Score Corrected Item } \\
\text { Total }\end{array}$ & Keterangan \\
\hline X & P1 & 0,929 & Valid \\
\cline { 2 - 4 } & P2 & 0,815 & Valid \\
\cline { 2 - 4 } & P3 & 0,922 & Valid \\
\hline P4 & 0,858 & Valid \\
\hline & P5 & 0,82 & Valid \\
\hline & P6 & 0,857 & Valid \\
\hline & P7 & 0,877 & Valid \\
\cline { 2 - 4 } & P8 & 0,81 & Valid \\
\hline Y & P9 & 0,776 & Valid \\
\cline { 2 - 4 } & P10 & 0,874 & Valid \\
\hline
\end{tabular}




\begin{tabular}{lcl}
\hline P11 & 0,824 & Valid \\
\hline P12 & 0,878 & Valid \\
\hline P13 & 0,87 & Valid \\
\hline P14 & 0,888 & Valid \\
\hline P15 & 0,903 & Valid \\
\hline P16 & 0,861 & Valid \\
\hline P17 & 0,87 & Valid \\
\hline P18 & 0,85 & Valid \\
\hline P19 & 0,884 & Valid \\
\hline P20 & 0,886 & Valid \\
\hline P21 & 0,84 & Valid \\
\hline P22 & 0,907 & Valid \\
\hline P23 & 0,82 & Valid \\
\hline
\end{tabular}

\section{Uji Reliabilitas X}

Setelah melakukan uji reliabilitas $X$, penulis mendapatkan hasil 0,966. Berdasarkan hasil tersebut, maka butir pertanyaan pada variabel $\mathrm{X}$ dapat dinyatakan reliabel karena nilai korelasi $>0,7$, yaitu $0,966>0,7$.

\section{Uji Reliabilitas Y}

Setelah melakukan uji reliabilitas Y, penulis mendapatkan hasil 0,979. Berdasarkan hasil tersebut, maka butir pertanyaan pada variabel $\mathrm{Y}$ dinyatakan reliabel karena nilai korelasi $>0,7$, yaitu $0,979>0,7$.

\section{Uji Normalitas}

Setelah dilakukan Uji One Sample Kolmogorov Smirnov yang ada pada aplikasi SPSS, penulis mendapatkan nilai signifikansi sebesar 0,636. Berdasarkan hasil tersebut, maka pernyataan di atas dinyatakan normal karena nilai signifikansi > 0,05 , yaitu $0,636>0,05$.

Setelah uji validitas, reliabilitas $\mathrm{X}$ dan $\mathrm{Y}$, serta uji normalitas dilakukan dan dinyatakan valid, reliabel, dan normal, maka semua pertanyaan tersebut dinyatakan layak untuk disebarkan kepada jumlah responden yang telah ditentukan, dalam hal ini adalah followers akun Instagram @ sisilism sebanyak 300 responden.

\section{Analisis Koefisien Korelasi}

Tabel 3. Hasil Analisis Koefisien Korelasi

\begin{tabular}{|c|c|c|c|}
\hline \multicolumn{4}{|c|}{ Correlations } \\
\hline & & motif & Kepuasan \\
\hline \multirow[t]{4}{*}{ motif } & Pearson & 1 & ,599** \\
\hline & Correlation & & \\
\hline & Sig. (2-tailed) & & , 000 \\
\hline & $\mathrm{N}$ & 300 & 300 \\
\hline \multirow[t]{4}{*}{ kepuasan } & Pearson &, $599^{* *}$ & 1 \\
\hline & Correlation & & \\
\hline & Sig. (2-tailed) & , 000 & \\
\hline & $\mathrm{N}$ & 300 & 300 \\
\hline
\end{tabular}


Setelah dilakukan analisis koefisien korelasi, hasil koefisien korelasi dari variabel $\mathrm{X}$ dan $\mathrm{Y}$ dalam penelitian ini adalah sebesar 0,599. Hal ini menunjukkan bahwa hubungan antara motif penggunaan media (X) memiliki korelasi yang cukup kuat terhadap kepuasan (Y).

\section{Analisis Koefisien Determinasi}

Tabel 4. Hasil Analisis Koefisien Determinasi

\begin{tabular}{lrrrr}
\hline \multicolumn{5}{c}{ Model Summary } \\
\hline Model & $\mathrm{R}$ & R Square & $\begin{array}{l}\text { Adjusted } \\
\text { R Square }\end{array}$ & $\begin{array}{c}\text { Std. Error of the } \\
\text { Estimate }\end{array}$ \\
\hline $\mathbf{1}$ & \multicolumn{1}{c}{, $599^{\mathrm{a}}$} &, 359 &, 357 & 5,65167 \\
\hline a. Predictors: (Constant), motif & &
\end{tabular}

Setelah dilakukan analisis koefisien determinasi, penulis mendapatkan hasil R Square sebesar 0,359. Hal ini menyatakan bahwa variabel $\mathrm{X}$ dapat menjelaskan terhadap variabel Y sebanyak 35,9\%, sedangkan $64,1 \%$ yang merupakan sisanya dipengaruhi oleh variabel lain.

\section{Analisis Regresi Linear Sederhana}

Tabel 5. Hasil Analisis Regresi Linear Sederhana

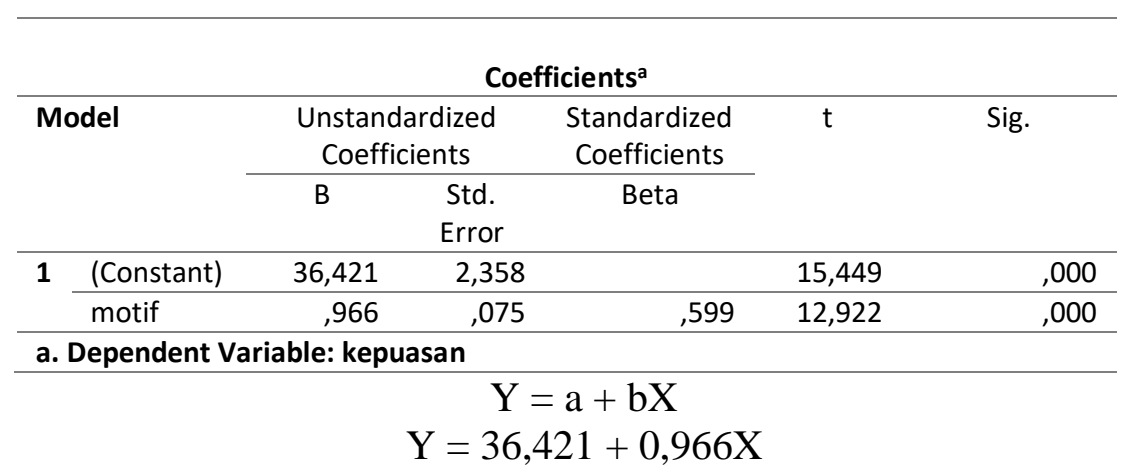

Berdasarkan hasil persamaan di atas, dapat disimpulkan bahwa konstanta sebesar 36,421 yang berarti bahwa nilai konsisten variabel kepuasan adalah sebesar 36,421. Sedangkan koefisien regresi X sebesar 0,966 yang menyatakan bahwa nilai kepuasan akan bertambah sebesar 36,421 setiap penambahan $1 \%$ nilai motif. Koefisien regresi tersebut bernilai positif, yang mengartikan bahwa arah pengaruh variabel X terhadap Y adalah positif. Hal ini dapat disimpulkan bahwa semakin besar akun Instagram @sisilism mampu mewujudkan semua keinginan followers dalam mencari informasi mengenai sex education, maka kepuasan followers akan turut meningkat juga. 


\section{Uji T}

Tabel 6 : Hasil Uji T

\begin{tabular}{|c|c|c|c|c|c|c|}
\hline \multicolumn{7}{|c|}{ ANOVA $^{a}$} \\
\hline \multicolumn{2}{|c|}{ Model } & $\begin{array}{l}\text { Sum of } \\
\text { Squares }\end{array}$ & df & $\begin{array}{l}\text { Mean } \\
\text { Square }\end{array}$ & $\mathrm{F}$ & Sig. \\
\hline \multirow[t]{3}{*}{1} & Regression & 5333,865 & 1 & 5333,865 & 166,989 &, $000^{b}$ \\
\hline & Residual & 9518,522 & 298 & 31,941 & & \\
\hline & Total & 14852,387 & 299 & & & \\
\hline \multicolumn{7}{|c|}{ a. Dependent Variable: kepuasan } \\
\hline \multicolumn{7}{|c|}{ b. Predictors: (Constant), motif } \\
\hline
\end{tabular}

Berdasarkan hasil perhitungan di atas, didapatkan nilai Sig. Sebesar 0,000 yang berarti apabila sig < 0,05 maka Ha diterima. Berarti hasil tersebut dapat disimpulkan bahwa variabel $\mathrm{X}$ memberikan pengaruh terhadap variabel $\mathrm{Y}$ (motif penggunaan media berpengaruh terhadap kepuasan).

Untuk mendapatkan hasil penelitian yang lebih dalam, peneliti juga melakukan penelitian guna mengetahui motif apa yang sebenarnya menjadi dasar para followers mengikuti akun Instagram @ sisilism. Menurut Mc Quail (2011 : 72), motif terbagi atas 4 , yakni motif informasi, motif identitas pribadi, motif integrasi dan identitas sosial, serta motif hiburan. Dari keempat motif penggunaan media yang ada, terdapat 2 (dua) motif yang paling dominan. Motif tertinggi pertama adalah motif identitas pribadi dengan nilai rata - rata sebesar 1344,5 dan motif tertinggi kedua diikuti oleh motif informasi dengan nilai rata - rata 1335.

Berdasarkan hasil rekapitulasi variabel X (motif penggunaan media), dimensi tertinggi ada pada dimensi motif indentitas pribadi dan motif informasi yang paling berpengaruh terhadap kepuasan followers.

\section{Kesimpulan}

Motif penggunaan media sosial Instagram @sisilism mempengaruhi secara signifikan kepuasan followers terkait sex education. Dengan temuan motif identitas pribadi yang berkaitan dengan tipe seksualitas dan motif informasi yang berkaitan dengan pengetahuan sex education sebagai dua dimensi tertinggi dari total empat dimensi motif penggunaan media yang mempengaruhi kepuasan followers dalam menggunakan media sosial Instagram @ sisilism terkait sex education. Berdasarkan hasil tersebut maka dapat disimpulkan juga bahwa Ha diterima dan Ho ditolak, serta penelitian ini juga mendukung konsep teori Uses and Gratification yang membahas tentang hubungan kepuasan dan kebutuhan pengguna terhadap sebuah media. Hasil penelitian ini mendukung konsep teori uses and gratification yang dikatakan Blummer dan Katz bahwa kepuasan pengguna media didasarkan pada motif atau alasan penggunaan media tersebut (Suryadi \& Widayatmoko, 2016:74). 


\section{Ucapan Terima Kasih}

Penulis mengucapkan banyak terima kasih kepada Bapak Drs. Widayatmoko, M.M., M.I.Kom., selaku dosen pembimbing yang telah membimbing penulis sehingga penelitian skripsi ini dapat berjalan lancar, serta Kak Sisil selaku pemilik akun Instagram @sisilism yang telah mengijinkan terlaksananya penelitian skripsi ini. Penulis juga mengucapan rasa terima kasih kepada orang tua, saudara, kerabat, dan responden yang telah memberikan dukungan dan bantuannya kepada penulis.

\section{Daftar Pustaka}

Atmadjati, A. (2018). Layanan Prima Dalam Praktik Saat Ini. Sleman: Deepublish. Budiargo, D. (2015). Berkomunikasi Ala Net Generation. Jakarta: PT Elex Media Komputindo Kompas Gramedia.

Gerungan, W. A. (2002). Psikologi Sosial. Jakarta: Refika Aditama.

Hatane Samuel, F. (2005). Pengaruh Kepuasan Konsumen Terhadap Kesetiaan Merek (Studi Kasus Restoran The Prime Steak \& Ribs Surabaya). Jurnal Manajemen \& Kewirausahaan, Vol. 7 No. 1, Maret 2005, 76.

https://health.detik.com/berita-detikhealth/d-4249233/gunung-es-perilaku-sekspranikah-di-kalangan-remaja dikases pada tanggal 9 Maret 2019 pada pukul 20.12 WIB

Luthfie, R. (2014). Fenomena Perilaku Seksual Pada Remaja (Sexual Behaviour Phenomena on Young People). Jurnal Ilmu Keperawatan Vol II No 2 September 2014, 3.

McQuail, D. (2011). Teori Media Massa. Jakarta: Salemba Humanika.

Nazir. (2011). Metode Penelitian. Bogor: Ghalia Indonesia.

Rakhmat, J. (2005). Psikologi Komunikasi. Bandung : Remaja Rosdakarya.

Sugiyono. (2017). Metode Penelitian Pendidikan (Pendekatan Kuantitatif, Kualitatif, dan $R \& D)$. Bandung: Alfabeta.

Suryadi \& Widayatmoko. (2016). Twitter Uses Satisfcation Among Young And Adults In Jakarta. International Conference of Communication, Industry, and Community, Bali, 74. 